\title{
PENINGKATAN PENGETAHUAN TERHADAP GANGGUAN KESEHATAN MATA, TELINGA HIDUNG DAN SALURAN PERNAFASAN YANG BERHUBUNGAN DENGAN KASUS AGROMEDICINE
}

\author{
Rani Himayani ${ }^{1)}$, Helmi Ismunandar ${ }^{1)}$, Mukhlis Imanto ${ }^{1)}$, Rasmi Zakiah Oktarlina ${ }^{1)}$, Ari Wahyuni ${ }^{1)}$ \\ 1) Fakultas Kedokteran Universitas Lampung, Bandar Lampung
}

Email : dr.ranihimayani@gmail.com/rani.himayani@fk.unila.ac.id /dr.helmiismunandar@gmail.com

\begin{abstract}
Abstrak
Latar Belakang: Indonesia merupakan negara dengan keanekaragaman hayati dan ekosistem pertanian dan perkebunan. Pekerja yang berada di sektor agrikultur seperti petani atau pekerja diperkebunan, ditemukan beberapa penyakit akibat kerja. Namun, rasio penyakit akibat kerja jauh lebih sulit untuk diukur, karena penyakit pribadi yang dimiliki oleh petani sulit diidentifikasi sebagai penyakit yang berhubungan dengan pekerjaannya. Penyakit akibat kerja cenderung sulit untuk ditegakkan karena terkadang saling tumpang tindih dengan penyakit lain di luar pekerjaan yang diderita oleh pekerja. Tujuan: Peningkatan pengetahuan masyarakat tentang gangguan kesehatan mata, telinga hidung dan saluran pernafasan yang berhubungan dengan kasus agromedicine pada komunitas keluarga dan pekerja di PTPN VII Way Berulu Kabupaten Pesawaran Lampung, sehingga penyakit karena pekerjaan dapat di cegah terutama saat usia produktif dan dilakukan deteksi dini untuk membantu skreening awal penyakit dilingkungan kerja di masyarakat terutama di PTPN VII Way Berulu Kabupaten Pesawaran. Metode : Metode penyuluhan masyarakat dan deteksi dini kesehatan mata, telinga hidung dan saluran pernafasan di PTPN VII Way Berulu. Hasil : Kegiatan diikuti oleh total 40 orang pekerja PTPN VII Way Berulu yang dipilih untuk menghadiri penyuluhan. Berdasarkan data hasil pengamatan pre-test, diketahui sekitar $57 \%$ peserta tidak paham mengenai pengetahuan kelainan mata merah/tukak kornea, gangguan pernafasan, rhinitis. Setelah dilakukan kegiatan penyuluhan, nilai hasil pengamatan meningkat. Sebagian besar peserta menjadi paham.
\end{abstract}

Kata kunci : Deteksi dini, mata merah, rhinitis, tukak kornea, ulkus kornea

\section{PENDAHULUAN}

Indonesia merupakan negara dengan keanekaragaman hayati dan ekosistem pertanian, luasnya potensi lahan subur untuk pertanian, melimpahnya tenaga kerja, tersedianya inovasi dan teknologi, serta besarnya potensi pasar dalam negeri dan internasional.

Sektor pertanian di Indonesia memegang peranan penting, mengingat lebih dari $40 \%$ angkatan kerjanya menggantungkan hidup di sektor ini. Berdasarkan data International Labour Organization (ILO), sekitar 1,3 juta orang bekerja di bidang pertanian di seluruh dunia. Dari angka tersebut, $60 \%$ diantaranya bekerja di negara berkembang. Tingkat kecelakaan fatal di negara berkembang empat kali lebih besar dari negara industri yang kebanyakan terjadi di bidang pertanian. (Haerani, 2010)

Penggunaan mesin-mesin dan alat-alat berat seperti traktor, mesin permanen, alat tanam dan sebagainya di sektor pertanian merupakan sumber bahaya yang dapat mengakibatkan cedera dan kecelakaan kerja yang fatal. Selain itu, penggunaan pestisida dapat menyebabkan keracunan atau penyakit yang serius, serta debu binatang dan tumbuhan yang mengakibatkan alergi, penyakit 
pernafasan dan trauma. Faktor lain yang memicu terjadinya kecelakaan kerja di bidang pertanian adalah terbatasnya waktu yang tersedia untuk menyelesaikan suatu pekerjaan yang diakibatkan oleh batasan iklim sehingga petani cenderung bekerja terburu-buru tanpa memperhatikan keselamatan dirinya (Donham K, Thelin 2006, Haerani, 2010)

Penyakit akibat kerja (PAK) adalah penyakit atau gangguan kesehatan yang diakibatkan oleh pekerjaan atau lingkungan kerjanya, dan diperoleh pada waktu melakukan pekerjaan dan masyarakat umum biasanya tidak akan terkena. Berat ringannya penyakit dan kondisi cacat tergantung dari jenis dan tingkat sakit (Depkes RI, 2008). Terdapat beberapa penyebab PAK yang umum terjadi di tempat kerja. Berikut merupakan beberapa jenis penyakit yang digolongkan berdasarkan penyebab yang ada di tempat kerja, yaitu 1)Golongan Fisik: bising, radiasi, suhu ekstrem, tekanan udara, vibrasi dan penerangan, 2)Golongan Kimiawi: semua bahan kimia dalam bentuk debu, uap, gas, larutan dan kabut, 3)Golongan Biologik: bakteri, virus, jamur dan lain-lain, 4)Golongan Fisiologik/Ergonomik: desain tempat kerja dan beban tempat kerja 5)Golongan Psikososial: stress psikis, tuntutan pekerjaan dan lain-lain.

Pra survey yang dilakukan di RSUD Abdul Moeloek Lampung diperoleh gambaran jumlah kasus ulkus kornea tahun 2004 sebanyak 40 kasus dan pada tahun 2005 terdapat 55 kasus. Penelitian di RSUD Abdul Moeloek Lampung pada tahun 2004-2005 terdapat 68 kasus ulkus kornea, pekerjaan buruh paling banyak menderita ulkus kornea $35,30 \%$ dan yang kedua terbanyak adalah petani $32,35 \%$, dengan pendidikan rendah $(\leq \mathrm{SMP})$, penyebab terbanyak ulkus kornea trauma $85,29 \%$. Faktor penyebab trauma terbanyak terjadinya kasus ulkus kornea di RSUDAM didahului trauma daun/biji padi, tumbuhan atau rumput sebanyak $27,95 \%$ dan yang kedua trauma benda asing atau kelilipan 25\%. (Himayani R, 2006)

Rinitis alergi adalah penyakit inflamasi yang disebabkan oleh reaksi alergi pada pasien atopi yang sebelumnya sudah tersensitisasi dengan alergen yang sama serta dilepaskannya suatu mediator kimia ketika terjadi paparan ulangan dengan alergen spesifik tersebut. Rinitis alergi diawali dengan tahap sensitisasi dan diikuti dengan reaksi alergi. Reaksi alergi terdiri dari 2 fase yaitu immediate phase allergic reaction atau reaksi alergi fase cepat (RAFC) yang berlangsung sejak kontak dengan alergen sampai 1 jam setelahnya dan late phase allergic reaction atau reaksi alergi fase lambat (RAFL) yang berlangsung 2-4 jam dengan puncak 6-8 jam (fase hiperreaktivitas) setelah pemaparan dan dapat berlangsung 24-48 jam.

Pneumonia merupakan penyebab utama kematian pada anak dibawah 5 tahun di seluruh dunia. Angka kejadian pneumonia di Asia Tenggara dan Afrika Selatan sekitar 146-159 juta kejadian pneumonia per tahun. Pada tahun 2013, pneumonia menyebabkan $5 \%$ dari total kematian balita di dunia. Walaupun dengan intervensi efektif telah berhasil menurunkan angka kematian pneumonia dari 4 juta di tahun 1981 menjadi 1 juta di tahun 2013, tetapi angka tersebut masih tetap tinggi. Di Eropa, insiden CAP pada anak sekitar 33/10.000 anak usia 0-5 tahun, dan 14,5/10.000 anak usia 0-16 tahun. Insiden pada anak laki-laki lebih tinggi pada semua kelompok usia. (Weber M, Handy F,2010 dan Mustapha MG dkk 2013)

Menurut Riskesdas tahun 2007, pneumonia merupakan penyakit penyebab kematian kedua setelah diare $(15,5 \%$ diantara semua balita) dan selalu berada pada daftar 10 penyakit terbesar setiap tahunnya di fasilitas kesehatan. Proporsi pneumonia menurut kelompok umur menunjukkan bahwa pneumonia pada balita memiliki proporsi yang lebih besar. Pada tahun 2007 dan 2008 perbandingan kasus pneumonia pada balita dibandingkan dengan usia $\geq 5$ tahun adalah $7: 3$, dan pada tahun 2009 terjadi perubahan menjadi $6: 4$. Selain itu, proporsi penemuan pneumonia pada bayi adalah sebesar $>20 \%$ dari semua kasus pneumonia.

Untuk memberikan pemahaman sekaligus mencegah kebutaan akibat kasus ulkus kornea, mata merah berulang dan rhinitis berulang karena alergi, serta kelainan saluran pernafasan pada anak yang mengancam jiwa maka penulis ingin melakukan Deteksi dan Penyuluhan Secara Komprehensif Kelainan di Bidang Mata, Telinga Hidung Tenggorok-Kepala Leher (THT-KL) dan Kesehatan paru-paru pada Komunitas Keluarga dan Pekerja di PTPN VII Way Berulu Kabupaten Pesawaran. Penyuluhan diberikan tidak hanya kepada tenaga pekerja PTPN VII Unit Way Berulu tetapi juga kepada keluarga pekerja agar masyarakat dapat 
mendeteksi dini karena penyakit-penyakit ini dapat dicegah.

\section{METODE}

Metode yang digunakan untuk pemecahan masalah dalam kegiatan ini adalah penyuluhan dan pemeriksaan bidang mata, THT-KL dan Saluran Pernafasan di komunitas pekerja dan keluarga PTPN VII Unit Way Berulu Pesawaran yang dilanjutkan dengan diskusi. Materi penyuluhan yang diberikan meliputi 4 kegiatan pengabdian (4 tema penyakit berhubungan dengan agromedicine), yaitu 1)Ulkus Kornea, 2)Konjungtivitis Alergika, 3)Rhinitis Alergika, 4)Pneumonia.

Pemeriksaan kelainan ulkus kornea dan konjungtivitis alergika oleh ahli mata untuk skreening dini. Pemeriksaan kelainan rhinitis alergika oleh ahli THT-KL dan pemeriksaan kelainan Pneumonia oleh tim dokter umum.

Penilaian yang dilakukan untuk menilai keberhasilan kegiatan ini terdiri dari evaluasi awal, evaluasi proses, dan evaluasi akhir. Evaluasi awal dilakukan dengan memberikan pre-test kepada peserta yang berisi beberapa pertanyaan yang terkait dengan materi yang diberikan. Hasil dari evaluasi ini berupa skor tiap peserta yang merupakan pembagian dari jawaban benar dengan total jumlah pertanyaan dikalikan 100 . Evaluasi proses dilakukan dengan melihat tanggapan para pekerja melalui pertanyaan-pertanyaan yang diajukan ataupun umpan balik yang diberikan dalam diskusi. Evaluasi akhir dilakukan dengan memberikan posttest yang berisi pertanyaan yang sama dengan pretest. Nilai post-test akan dibandingkan dengan pretest. Apabila nilai post-test lebih tinggi dibandingkan pre-test maka penyuluhan yang diberikan berhasil meningkatkan pengetahuan mengenai kelainan ulkus kornea, konjungtivitis alergika, rhinitis alergika dan pneumonia. Pemeriksaan dilakukan pencatatan dan didata, apabila ada yang mengalami kelainan di bidang mata, THT-KL dan kesehatan paru disarankan ke pelayanan kesehatan untuk mendapatkan terapi awal.

\section{HASIL DAN PEMBAHASAN}

Kegiatan diikuti oleh total 40 orang pekerja PTPN VII Way Berulu yang dipilih untuk menghadiri penyuluhan. Berdasarkan data hasil pengamatan pre-test, diketahui sekitar $57 \%$ peserta tidak paham mengenai pengetahuan kelainan mata merah/tukak kornea, konjungtivitis alergika, gangguan pernafasan, rhinitis. Setelah dilakukan kegiatan penyuluhan, nilai hasil pengamatan meningkat. Setelah dilakukan kegiatan penyuluhan, nilai hasil pengamatan meningkat. Sebagian besar peserta menjadi paham mengenai pengetahuan kelainan mata merah/tukak kornea, konjungtivitis alergika, gangguan pernafasan, rhinitis. Setelah dilakukan post-test, dari data yang diperoleh semua peserta sudah paham $(100 \%)$ terhadap pengetahuan kelainan mata merah/tukak kornea, konjungtivitis alergika, gangguan pernafasan, rhinitis.

Hasil skreening kelainan mata untuk kasus tukak kornea, kelainan pernafasan dan rinitis tidak ditemukan.Kelainan mata merah tanpa gangguan penglihatan, yaitu pterygium derajat 1 terdapat 3 kasus, namun masih dapat di observasi saja karena tidak ada keluhan.

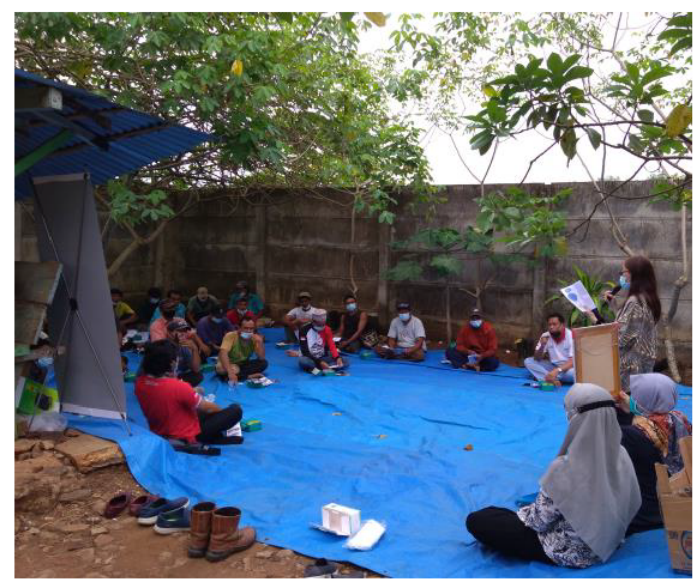

Gambar 1. Penyuluhan dibidang mata 


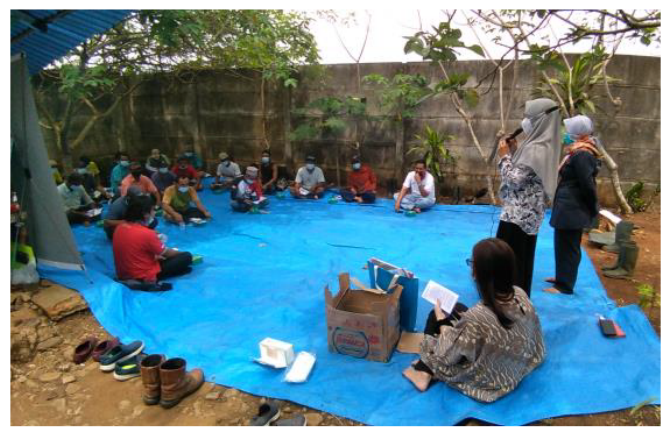

Gambar 2. Penyuluhan gangguan saluran pernafas an dan rinitis

Faktor predisposisi terbanyak pada ulkus kornea baik infeksius dan non-infeksius adalah trauma mata. Di Rumah Sakit Sardjito Yogyakarta, trauma kornea merupakan penyebab terbanyak $(68,4 \%)$ terjadinya ulkus kornea (Suhardjo et al., 2000).

Trauma mata banyak terjadi akibat benda asing salah satunya adalah bahan yang berasal dari tumbuh-tumbuhan oleh karena itu ulkus infeksius banyak dialami pada orang yang bekerja di sektor pertanian. Salah satu ulkus kornea non-infeksius yaitu ulkus Mooren banyak dialami pada orang yang bekerja sebagai petani. Ulkus kornea infeksius dan non-infeksius lebih banyak terjadi di daerah rural atau pedesaan dibanding dengan daerah urban atau perkotaan (Nagasree dan Vijayalakshmi, 2015)

Gambaran klinik ulkus kornea dapat berupa gejala subjektif dan gejala objektif. Gejala subjektif yang timbul berupa eritema pada kelopak mata dan konjungtiva, sekret, merasa ada benda asing di mata, pandangan kabur, mata berair, bintik putih pada kornea, silau, dan nyeri. Gejala objektif yang timbul berupa injeksi silier, hilangnya epitel kornea, adanya infiltrat, dan hipopion (Ilyas 2014, Lubis MA 2015).
Diagnosis ulkus kornea dapat dilakukan dengan pemeriksaan klinis yang baik dibantu dengan slitlamp. Pada pemeriksaan ketajaman penglihatan atau visus, didapatkan adanya penurunan visus. Penelitian yang dilakukan Ezegwui (2010) di Afrika menunjukan bahwa dari 82 pasien ulkus kornea sebanyak 55 pasien mengalami penurunan visus kurang dari $3 / 60$. Jenis mikroorganisme ditegakkan berdasarkan pemeriksaan mikroskopik dan kultur. (Lubis MA, 2015)

Tujuan penatalaksanaan ulkus komea adalah eradikasi bakteri dari kornea, menekan reaksi peradangan sehingga tidak memperberat destruksi pada kornea, mempercepat penyembuhan defek epitel, mengatasi komplikasi, serta memperbaiki tajam penglihatan. (Himayani $\mathrm{R} \mathrm{dkk}, 2006$, AAO 2012, Infodatin 2015)

Rinitis alergi adalah penyakit inflamasi yang disebabkan oleh reaksi alergi pada pasien atopi yang sebelumnya sudah tersensitisasi dengan alergen yang sama serta dilepaskannya suatu mediator kimia ketika terjadi paparan ulangan dengan alergen spesifik tersebut. Menurut WHO ARIA (Allergic Rhinitis and its Impact on Asthma) tahun 2001, rinitis alergi adalah kelainan pada hidung dengan gejala bersin-bersin, rinore, rasa gatal dan tersumbat setelah mukosa hidung terpapar alergen yang diperantarai oleh $\operatorname{IgE}$.

Rinitis alergi melibatkan interaksi antara lingkungan dengan predisposisi genetik dalam perkembangan penyakitnya. Faktor genetik dan herediter sangat berperan pada ekspresi rinitis alergi. Penyebab rinitis alergi tersering adalah alergen inhalan pada dewasa dan ingestan pada anak-anak. Pada anak-anak sering disertai gejala alergi lain, seperti urtikaria dan gangguan pencernaan. Penyebab rinitis alergi dapat berbeda tergantung dari klasifikasi. Beberapa pasien sensitif terhadap beberapa alergen. Alergen yang menyebabkan rinitis alergi musiman biasanya berupa serbuk sari atau jamur. (Riskesdas 2007)

Pneumonia adalah peradangan yang terjadi pada parenkim paru sebelah distal bronkus terminalis yang bisa meliputi bronkiolus respiratorius, duktus alveolaris, alveoli, dan jaringan intertisial paru. Pembagian pneumonia secara anatomis meliputi pneumonia lobaris, pneumonia lobularis (bronkopneumonia), dan pneumonia intertisialis (bronkiolitis).Eksudat mukopurulen yang dihasilkan 
oleh peradangan tersebut akan menyebabkan penyumbatan pada saluran-saluran nafas kecil dan menghasilkan bercak-bercak konsolidasi pada lobulus-lobulus paru yang berdekatan. (Kumar V dkk 2011, Sandora TJ dkk 2011)

Dalam keadaan sehat, pada paru tidak akan terjadi pertumbuhan mikroorganisme. Keadaan ini disebabkan oleh adanya mekanisme pertahanan paru. Terdapatnya bakteri di dalam paru merupakan ketidakseimbangan antara daya tahan tubuh sehingga mikroorganisme dapat berkembang biak dan berakibat timbulnya infeksi penyakit. Bila pertahanan tubuh tidak kuat maka mikroorganisme dapat melalui jalan nafas sampai ke alveoli yang menyebabkan radang pada dinding alveoli dan jaringan sekitarnya. Setelah itu mikroorganisme tiba di alveoli membentuk suatu proses peradangan yang meliputi empat stadium, yaitu hiperemia, hepatisasi merah, hepatisasi kelabu, dan resolusi. Dasar tatalaksana pneumonia adalah pengobatan kausal dengan antibiotik yang sesuai, serta tindakan suportif. (WHO 2009, Ostapchuk M dkk 2004, Mustapha MG dkk 2013).

\section{KESIMPULAN}

Pengabdian ini dapat membantu masyarakat terdeteksi awal apabila terdapat gangguan kesehatan mata, telinga-hidung dan saluran pernafasan yang berhubungan dengan kasus Agromedicine pada komunitas keluarga dan pekerja di PTPN VII Way Berulu Kabupaten Pesawaran Lampung sehingga segera mendapat penanganan yang tepat dan memberi masukan ilmu yang bermanfaat dalam dunia medis..

\section{UCAPAN TERIMAKASIH}

Kami ucapkan terima kasih kepada jajaran Pimpinan PTPN VII Way Berulu atas partisipasinya dalam rangka penyuluhan bidang kesehatan untuk peningkatan pengetahuan para pekerja PTPN VII Way Berulu.

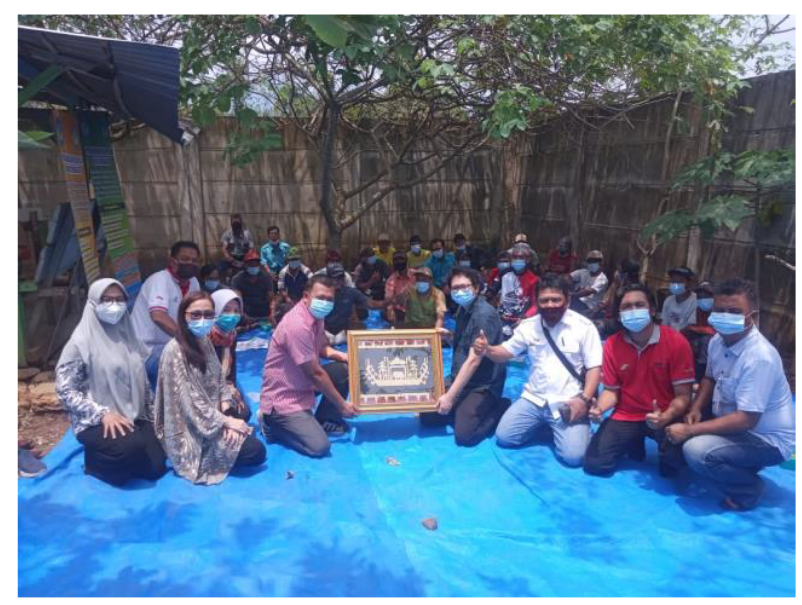

Gambar 3. Kegiatan penyuluhan bersama pimpinan PTPN VII Way Berulu dan para pekerja PTPN VII Way Berulu.

\section{REFERENSI}

1. Haerani. (2010). Penerapan Keselamatan dan Kesehatan Kerja di Bidang Pertanian di Indonesia. Media Kesehatan Masyarakat Indonesia (Vol. 6, No. 3). http://portalgaruda.org/indcleex.php?ref=br owse\&mod=viewarticle\&article $=16579$.

2. Mustapha MG, Ashir GM, Alhaji MA, Rabasa AI, Ibrahim BA, Mustapha Z. Presentation, complications and management outcome of community acquired pneumonia in hospitalized children in Maiduguri, Nigeria. Niger J Paed 2013; 40 (1) : 30-3.

3. Weber M, Handy F. Situasi pneumonia balita di Indonesia. Buletin Jendela Epidemiologi. 2010:1-10

4. Ostapchuk M, Roberts DM, Haddy R. Community-acquired pneumonia in infants and children. Am Fam Physician. 2004;70:899-908

5. Pulmonary Infection. In : Basic Pathology, $8^{\text {th }}$ Ed. Kumar V, Abbas AK, Fausto N, Mitchell R. Bradley JS, Byington CL, Shah SS, Alverson B, Carter ER, Harrison C, et al. The management of communityacquired pneumonia in infants and children older than 3 months of age: clinical practice guidelines by the Pediatric Infectious Diseases Society and the Infectious 
Diseases Society of America. Clin Infect Dis. 2011:e1-52

6. Sandora TJ, Sectish TC. Communityacquired pneumonia. In: Kliegman RM, Stanton HB, Behrman RE, editors. Nelson Textbook of Pediatrics. Philadelphia: WB Saunders Company; 2011. p. 1474-9

7. Global action plan for prevention and control of pneumonia (GAPP): WHO/UNICEF; 2009

8. American Academy of Ophthalmology. Section: External Eye Disease. Basic and Clinical Science Course. San Fransisco. 2011-2012

9. British Journal of Ophthalmology May 2018. keratitis.102 (5) 604-610; DOI: 10.1136/bjophthalmol-2017-310642

10. Himayani R, Shara J, Bangsawan M. Gambaran Karakteristik Kasus Ulkus Kornea di RSUD Dr. H. Abdoel Moeloek Lampung Periode Tahun 2004-2005. 2006. Skripsi. Universitas Lampung

11. Ilyas S. Ilmu Penyakit Mata. Edisi 5. 2014. Salemba Medika Jakarta
12. Infodatin. Pusat Data dan Informasi. 2015. Kementerian Kesehatan Republik Indonesia.

13. Donham K, Thelin. Agricultural Medicine : Rural Occupational and Environmental Health, Safety and Prevention. Second Edition . 2006.

14. Lubis MA(2015). Gambaran ulkus kornea pasien rawat inap di bangsal mata RSUP. Dr. M. Djamil Padang tahun 2011-2013. Fakultas Kedokteran Universitas Andalas.Skripsi.

15. Nagasree DVC, Vijayalakshmi G(2015). Ulcerative Keratitis a Prospective Hospital based Clinical and Microbiological Study. Journal of Evidence based Medicine and Healthcare,2(9): 1252-1262

16. Riset Kesehatan Dasar (Riskedas). 2007. Badan Penelitian dan Pengembangan. Kementerian Kesehatan Republik Indonesia. 